\title{
ANALISIS ASOSIASI MEREK HANDPHONE NOKIA, SIEMENS DAN SONY ERICSSON DI KOTAMADIA YOGYAKARTA
}

\author{
Albari \\ Fakultas Ekonomi Universitas Islam Indonesia \\ Anindyo Pramudito \\ Alumnus Fakultas Ekonomi Universitas Islam Indonesia
}

\begin{abstract}
Abstrak
Asosiasi merek merupakan dasar untuk kualitas pembentukan citra merek dan ekuitas merek. Bagi pemasar, asosiasi merek berguna dalam banyak hal, terutama untuk pengambilan keputusan dan perluasan merek produknya, sedangkan bagi konsumen bisa dijadikan untuk dasar dalam pemilihan merek yang bermanfaat untuk memenuhi kebutuhan dan keinginannya. Dengan menggunakan 288 responden di Kotamadia Yogyakarta, penelitian ini mencoba mengidentifikasi asosiasi merek dari handphone merek Nokia, Siemens, dan Sony Ericsson melalui metode Cochran Q test. Hasil penelitian menunjukkan ada 6 (enam) asosiasi yang bisa dimanfaatkan untuk meningkatkan citra dan ekuitas merek Nokia, sementara untuk Siemens dan Sony Ericsson masing-masing sebanyak 4 (empat) dan 10.

Penelitian ini juga memetakan asosiasi masing-masing merek handphone berdasarkan katagori konsumen melalui pendekatan Chi Square test. Hasilnya menunjukkan bahwa kelompok konsumen pria cenderung menyatakan bahwa Nokia dan Sony Ericsson sebagai handphone yang mudah digunakan untuk komunikasi, sedangkan konsumen wanita lebih cenderung menilai Siemens sebagai handphone yang ringan dibawa. Dari sudut pandang pelajar dan mahasiswa Sony Ericsson juga dianggap sebagai produk berkualitas dan mempunyai bentuk yang fashionable.
\end{abstract}

Kata Kunci: Ekuitas merek, citra merek, asosiasi merek.

\section{PENDAHULUAN}

Dalam kondisi persaingan usaha yang semakin ketat saat ini perusahaan perlu memanfaatkan sumber dayanya dengan optimal, termasuk berusaha menciptakan atau melakukan rekayasa yang dapat mempengaruhi persepsi konsumen, misalnya melalui citra merek produknya. Menurut Kotler (2003) merek sebenarnya merupakan janji penjual untuk secara konsisten memberikan tampilan, manfaat, dan jasa tertentu kepada pembeli, dan karena itu keahlian paling utama dari pemasar adalah kemampuannya untuk menciptakan, memelihara, melindungi dan meningkatkan merek. Perusahaan yang mempunyai citra merek yang kuat mempunyai alternatif untuk bersaing pada tingkat harga dan spesifikasi produk (Aaker, 1992b). Dengan memiliki citra merek yang kuat perusahaan dapat tetap bersaing, merebut dan bahkan memenangkan persaingan pasar.

Menurut Low dan Lamb Jr (2000) citra merek adalah persepsi tentang suatu merek sebagai refleksi asosiasi merek yang terbentuk dalam ingatan konsumen. Menurut mereka, bagian dari asosiasi merek adalah persepsi kualitas dan sikap terhadap merek. Sedangkan identifikasi asosiasi merek dapat didasarkan dengan 
meningkatkan akses terhadap asosiasi yang tersembunyi, bantuan responden yang menyatakan tentang asosiasinya, mengurangi penyensoran tanggapan, dan validasi laporan (Supphellen, 2000). Tetapi asosiasi merek sebagai bagian dari katagorisasi merek juga dapat ditentukan dengan menggunakan ketidakpastian sebagai dimensi intrinsik, sehingga dapat diperoleh segmen dan struktur pasar; sementara ketidakpastian tersebut dapat berupa pikiran terhadap merek individu, merek relatif dan unsur persepsi resiko (Davis, 2002).

Keunggulan persaingan yang didasarkan pada fungsi merek dapat menghasilkan citra merek yang positif serta menciptakan keunggulan kinerja dan profitabilitas perusahaan, laba jangka panjang dan potensi pertumbuhan (Del Rio et al, 2001). Untuk mencapai hasil tersebut, menurut Keller (1993) strategi yang efektif untuk menciptakan asosiasi merek yang kuat adalah dengan memadukan bauran komunikasi (promosi), yaitu dengan periklanan, promosi penjualan, publisitas, pemasaran langsung dan kemasan yang didesain secara khusus.

Masalahnya adalah munculnya kesadaran tentang pentingnya merek dan usaha-usaha untuk meningkatkan nilai merek tidak hanya dilakukan oleh suatu perusahaan saja, tetapi oleh seluruh perusahaan yang menghasilkan katagori produk yang ada atau relatif sama. Hal ini menimbulkan peta persaingan menjadi ketat. Di antara kelompok merek yang persaingannya cukup ketat di Indonesia adalah produk handphone.

Pada masa sekarang ini, handphone atau telepon genggam telah menjadi alat komunikasi paling dicari oleh seluruh lapisan masyarakat, bukan hanya golongan masyarakat yang memiliki aktivitas mobile. Begitu populernya handphone ini, sehingga alat komunikasi ini telah menjadi trend baru dan tampaknya tidak dapat terpisahkan dari kebutuhan dan gaya hidup manusia Indonesia, terutama di kota-kota besar. Bahkan tampaknya handphone sudah menjadi salah satu dari consumer goods yang telah berubah kondisinya dari kelompok barang mewah menjadi barang belanja yang lebih mudah diperoleh konsumen.

Merek-merek dari jenis produk ini tidak hanya bersaing dalam kecanggihan teknologi, tetapi juga misalnya pelayanan purna jual, harga, variasi bentuk, kejernihan suara, garansi pembelian dan kemudahan penggunaan. Nokia misalnya, mengklaim sebagai handphone yang paling userfriendly, teknologi dan desainnya senantiasa up to date, nilai jual kembali yang tetap bagus dan after sales service-nya ada dimana-mana (Firdanianty, 2003). Lebih jauh survey merek yang dilakukan SWA (2003) bersama MARS menunjukkan keperkasaan Nokia dibandingkan dengan merek lain. Jika tahun sebelumnya Nokia berada pada peringkat pertama, maka kedudukan tersebut berhasil dipertahankan pada tahun 2003. Sementara itu peringat Siemens dan Sony Ericsson tidak stabil. Jika tahun sebelumnya Ericsson berada di peringkat kedua dan disusul oleh Siemens, maka pada tahun 2003 mereka bertukar peringkat, yaitu Siemens di peringkat dua diikuti oleh Sony Ericsson di peringkat tiga.

Keperkasaan dan atau perubahan peringkat nilai merek handphone tersebut kemungkinan adanya dinamisasi asosiasi merek di benak konsumen. Karena itu 
studi tentang asosiasi merek handphone ini perlu dilakukan untuk dapat mengungkap keunggulan asosiasi merek handphone yang satu dibandingkan dengan merek handphone yang lain. Hasil studi selanjutnya dapat digunakan oleh pemasar sebagai dasar pengambilan keputusan untuk mengeksploitasi asosiasi merek-merek tersebut di bidang pemasaran.

\section{KAJIAN PUSTAKA DAN HIPOTESIS}

\section{Ekuitas Merek, Citra Merek dan Asosiasi Merek}

Keberadaan suatu merek seringkali dapat melebihi usia pemilik perusahan atau ketahanan aset perusahaan yang lain, seperti masa kerja mesin produksi, bangunan gedung dan bahkan umur ekonomis produknya. Demikian pula proses merger atau akuisisi suatu perusahaan dengan perusahaan yang lain seringkali berlarut-larut, karena belum terjadinya kesepakatan harga yang disebabkan tingginya nilai suatu merek yang mungkin bisa melampaui nilai aset tangibel perusahaan. Kondisi tersebut tidak terlepas dari ekuitas merek yang dimiliki perusahaan serta citra merek dan asosiasi suatu merek yang dipersepsikan konsumen.

Ekuitas merek adalah sekelompok aset dan liabilitas yang berhubungan dengan merek, nama dan simbol, yang menambah atau bagian dari nilai produk dan jasa perusahaan dan pelanggan (Aaker, 1991; Washburn et al, 2000). Ekuitas merek muncul sebagai prioritas bisnis dan pemasaran yang sangat penting (Grace dan O'cass, 2002). Nama merek misalnya sacara eksplisit membawa manfaat suatu produk lebih tinggi dari manfaat suatu pesan iklan yang konsisten (Keller et al, 1998), karena mampu mempengaruhi pemahaman merek melalui tanggapan konsumen tentang merek (Washburn et al, 2000; Grace dan O'cass, 2002), dan dibutuhkan pemasar untuk mengelola asosiasi merek (Grace dan O'cass, 2002). Di samping itu, Mackay (2001) menemukan bahwa pengukuran ekuitas juga dipercaya manajer, karena dapat mengumpulkan banyak data empiris dengan mudah dan dengan biaya murah. Data tersebut misalnya berupa katagorisasi produk dan atribut produk, pilihan merek tertentu, minat pembelian dan kualitas merek. Sementara untuk menghadapi lingkungan digital, pemasar perlu memperhatikan fleksibilitas nama merek, pemasaran yang terpadu, keunggulan yang berbeda, keterlibatan konsumen yang maksimum, dan proaktif dalam pelayanan pelanggan (Upshaw, 2001).

Keller (1993) berpendapat bahwa pemahaman terhadap isi dan struktur merek penting dilakukan, karena mereka mempengaruhi munculnya ingatan ketika konsumen berpikir tentang suatu merek. Dimensi yang dapat membedakan pemahaman merek dan mempengaruhi tanggapan konsumen adalah kesadaran merek (dalam hubungannnya dengan pesan dan pengenalan merek), kebaikan, kekuatan dan keunikan asosiasi merek di dalam ingatan konsumen. Sementara kesadaran merek memberi pengaruh penting dalam pengambilan keputusan, karena berkaitan dengan katagori produk, pertimbangan kelompok, serta bentuk dan kekuatan asosiasi merek pada citra merek. Sementara Aaker (1992b) mengusulkan bahwa untuk 
mengembangkan merek yang kuat, 5 (lima) hal dapat dilakukan untuk membantu strategi perusahaan, yaitu identitas merek yang jelas, adanya merek perusahaan, memadukan komunikasi yang konsisten, hubungan dengan pelanggan serta adanya simbol dan slogan.

Hubungan antara ekuitas merek dengan citra merek ditunjukkan oleh Keller (1998), yang menyatakan bahwa citra merek merupakan komponen penting untuk meningkatkan ekuitas merek. Menurut Keller (1998) serta Low dan Lamb Jr (2000) citra merek adalah persepsi tentang suatu merek sebagai refleksi asosiasi merek yang terbentuk dalam ingatan konsumen. Keunggulan persaingan yang didasarkan pada fungsi merek dapat menghasilkan citra merek yang positif serta menciptakan keunggulan kinerja dan profitabilitas perusahaan, laba jangka panjang dan potensi pertumbuhan (Del Rio et al, 2001). Selain itu perusahaan yang mempunyai citra merek yang kuat mempunyai alternatif untuk bersaing pada tingkat harga dan spesifikasi produk (Aaker, 1992b). Pada tingkatan katagori merek, nama merek, pengalaman lampau dengan merek dan kualitas produk inti juga dapat menjadi pertimbangan utama konsumen (Grace dan O'cass, 2002).

Adapun asosiasi merek, selain sebagai refleksi dari citra merek, seperti yang dinyatakan Keller (1998) serta Low dan Lamb Jr (2000), juga mempunyai peran penting membentuk ekuitas merek. Merek dengan jumlah asosiasi yang banyak cenderung menimbulkan ekuitas merek yang tinggi pula (Washburn at al, 2001). Demikian pula asosiasi nama merek sebagai unsur merek privat produk dapat berpengaruh positif terhadap penilaian konsumen terhadap produk yang tidak familier dengan mereka (Vaidyanathan dan Aggarwal, 2000).

\section{Pentingnya Asosiasi Merek}

Asosiasi merek adalah sesuatu yang berhubungan dengan ingatan pada merek dan memuat arti penting suatu merek bagi konsumen (Keller, 1998; Del Rio et al, 2001); atau sesuatu yang berhubungan dengan ingatan suatu merek (Aaker, 1991), baik secara langsung maupun tidak langsung (Aaker, 1992a). Faktor penting asosiasi tersebut adalah situasi penggunaan dan pemakai produk, selebriti, gaya hidup dan perasaan, kelas produk atau simbol (Aaker, 1991; Aaker, 1992a); serta atribut produk, manfaat, harga, pesaing, abstrak dan lokasi geografis (Aaker, 1992b). Sedangkan menurut Aaker dan Joachimsthaler (dalam Davis, 2002) asosiasi merek adalah sesuatu yang menghubungkan konsumen dengan merek, termasuk di dalamnya penggunaan perbandingan, atribut produk, pemanfaatan situasi, asosiasi organisasional, personalitas merek dan simbol-simbol.

Del Rio et al (2001) berhasil membuktikan beberapa hipotesa, yaitu bahwa (1) asosiasi merek yang berkaitan dengan jaminan pemakaian produk, identifikasi personal, dan status sosial secara positif berpengaruh terhadap kesediaan konsumen untuk menggunakan kembali merek tersebut atau kelompok produk yang lain; (2) asosiasi merek yang berkaitan dengan pemakaian produk dan identifikasi personal secara positif berpengaruh terhadap kesediaan memberikan rekomendasi 
kepada orang lain; dan (3) asosiasi merek yang berkaitan dengan pemakaian produk dan identifikasi sosial secara positif berpengaruh terhadap kesediaan konsumen membeli dengan harga yang lebih tinggi.

Menurut Chen (2001) asosiasi merek dapat dibagi menjadi asosiasi produk dan asosiasi organisasi. Asosiasi produk berupa asosiasi atribut fungsional, seperti atribut produk, persepsi kualitas dan manfaat fungsional; serta asosiasi atribut non fungsional, seperti asosiasi simbolik, emosional, harga/nilai, dan pemakai atau stuasi penggunaan. Asosiasi organisasi berhubungan dengan asosiasi kemampuan perusahaan, yaitu berupa keahlian menghasilkan dan mengirimkan hasil (produk), seperti keahlian karyawan, keunggulan bagian penelitian dan pengembangan internal, hasil inovasi teknologi dan kepemimpinan industri; serta asosiasi pertanggungjawaban sosial perusahaan, yang berupa refleksi status dan kegiatan perusahaan dengan memperhatikan peningkatan tanggungjawab sosial, ramah dan terlibat dengan lingkungannya.

Assosiasi mempunyai tingkatan kekuatan, yang dapat menciptakan citra merek dan menjadi dasar untuk keputusan pembelian dan loyalitas merek (Aaker, 1991). Asosiasi sangat penting untuk memahami efektifitas media, sebagai ingatan pesan merek, serta berfungsi untuk menetapkan hubungan unsur-unsur kegiatan dan merek yang berbeda (Quester dan Farrely, 1998). Menurut Uggla (2004) asosiasi merek juga berkaitan dengan keunggulan merek, perluasan yang berhubungan dengan perpindahan identitas atau citra melalui kelompok merek, dan atau asosiasi institusional yang mendukung secara positif/negatif untuk mengartikan merek atau nilai. Assosiasi merek juga merupakan aset yang dapat meningkatkan nilai, dan sebagai dasar penting untuk melakukan pembedaan, keunggulan kompetitif, mempengaruhi keputusan pembelian, mendorong perasaan dan sikap positif dan peningkatan pembelian (Aaker, 1992a).

Sementara itu, menurut Keller (1993) asosiasi merek sangat relevan dengan kebaikan, kekuatan dan keunikan dari atribut, fungsi, pengalaman dan manfaat simbolik produk. Keberhasilan program pemasaran merupakan refleksi kreatifitas asosiasi merek yang disukai; konsumen mempercayai suatu merek mempunyai atribut dan manfaat yang memuaskan kebutuhan dan keinginan mereka. Kekuatan asosiasi merek berfungsi sebagai pemrosesan informasi dari pesan yang diterima, baik dalam jumlah dan kualitas. Sedangkan keunikan asosiasi merek berkaitan dengan komunikasi yang secara eksplisit dapat dibandingkan dengan pesaing atau hal penting yang implisit tanpa penyebutan referensi persaingan.

Lebih lanjut Keller (1998) juga menyatakan asosiasi merek dapat menciptakan citra merek berdasarkan pada tipe, kebaikan, kekuatan dan keunikannya. Tipe asosiasi merek dapat berasal dari atribut, manfaat dan sikap terhadap merek. Atribut terdiri dari atribut produk dan atribut non produk, seperti harga, pemakai dan situasi penggunaan, personalitas merek serta perasaan dan pengalaman. Sedangkan manfaat merek berasal dari fungsi, pengalaman penggunaan, dan simbol merek. Kebaikan merek berhubungan dengan hirarki kebutuhan Maslow, yaitu kebutuhan 
fisik, kaamanan, sosial, penghargaan dan aktualisasi diri. Kekuatan merek berupa tingkatan tipe asosiasi merek yangmenentukan konsumen dalam pengambilan keputusan pembelian maupun untuk menginformasikan kepada orang lain. Sedangkan keunikan berkaitan dengan sesuatu/perbedaan yang dimiliki oleh suatu merek dibandingkan dengan merek lain atau katagori produk lain.

Dari paparan di atas dapat dinyatakan bahwa asosiasi merek berguna bagi konsumen, manajer/perusahaan maupun pihak lain. Bagi konsumen, asosiasi merek dapat membantu proses, mengorganisir, dan mendapatkan kembali informasi dalam ingatan dan untuk membantu pegambilan keputusan (Aaker, 1991; Low dan Lamb Jr, 2000), di samping melalui nama merek dan atribut produk dapat berguna untuk memprediksi kinerja produk dan pencarian informasi (Janiszewski dan Van Osselaer, 2000). Konsumen dapat mengembangkan keragaman asosiasi nama merek dan kemudian mengelompokkan dalam co-branding produk, memproses informasi, membedakan merek, membantu pilihan pembelian yang rasional, menciptakan sikap dan perasaan positif, serta memberikan dasar menciptakan rasa kesesuaian antara nama merek dan produk baru (Washburn at al, 2000).

Bagi manajer, asosiasi merek dibutuhkan untuk mendefinisikan strategi merek secara optimal, desain komunikasi yang efektif dan untuk memahami lingkungan persaingannya (Suppheller, 2000). Pemasar juga bisa menggunakan asosiasi merek untuk membedakan dalam memposisikan dan memperluas merek, menciptakan sikap dan perasaan positif terhadap merek, mengesankan atribut dan manfaat pembelian atau penggunaan merek secara khusus (Low dan Lamb Jr, 2000). Perbedaan asosiasi dari konsumen akan konsisten dengan indikator ekuitas ekternal dan memberikan pengetahuan kekuatan dan kelemahan setiap merek, sehingga dapat digunakan untuk penguatan merek (Krishnan, 1996). Di samping itu, asosiasi merek produk juga berguna membantu seseorang memahami positioning produk dan mengenal potensi pemanfaatan situasi pembelian (Janiszewski dan Van Osselaer, 2000).

\section{Pengukuran Asosiasi Merek}

Asosiasi merek tidak bersifat tetap sepanjang hidup merek. Asosiasi merek mungkin berubah menurut isi, penggunaan, tingkat penyerapan, perubahan dari konkrit dan spesifik menjadi abstrak dan general, selain asosiasi merek mungkin merubah dengan kuat hubungan merek dengan asosiasi yang lain, seperti kenaikan pembelian, kesukaan konsumen, reputasi, citra, reputasi, kualitas merek yang tinggi, tingginya nilai merek, sikap positif dan kepemilikian sebelumnya (Hoeffler dan Keller, 2003). Karena itu penelitian secara terus menerus perlu dilakukan untuk memperoleh pemahaman asosiasi merek yang terbaru.

Menurut Keller (1998) pengukuran asosiasi merek dapat dilakukan dengan skala absolut atau perbandingan; skala verbal, skor, atau spasial; skala jumlah atau titik; skala perimbangan; dan skala dengan tanggapan ya atau tidak. Skala ya atau tidak ini pernah dilakukan oleh Quester dan Farrely (1998). Menurut Simamora 
(2003), pada kasus tertentu, jenis tanggapan ya atau tidak, bisa menghindari kelemahan pendekatan multiatribut, keseluruhan dimensi yang diukur direduksi menjadi lebih sedikit faktor. Dalam kaitannya dengan segmentasi pasar Keller (1998) juga berpendapat bahwa pengukuran asosiasi merek dapat merujuk dengan karakteristik konsumen, seperti demografi.

\section{Hipotesa}

Berdasarkan pemaparan di atas, maka hipotesa pengukuran asosiasi merek untuk masing-masing handphone merek Nokia, Siemens, atau Sony Ericsson ini adalah:

H1 : Semua asosiasi merek handphone (Nokia, Siemens, atau Sony Ericsson) mempunyai proporsi jawaban "ya" yang sama

H2 : Ada perbedaan asosiasi merek handphone merek Nokia, Siemens, atau Sony Ericsson menurut karakteristik konsumen

\section{METODE PENELITIAN}

\section{Subyek Penelitian dan Pengumpulan Data}

Subyek penelitian ini adalah konsumen di wilayah kotamadia Yogyakarta yang pernah menggunakan produk handphone merek Nokia, Siemens, atau Sony Ericsson. Sedangkan pengumpulan data dilakukan melalui 2 (dua) tahap penyebaran angket kepada sampel penelitian.

Angket pertama bersifat setengah terbuka, disebarkan dengan maksud untuk mengidentifikasikan asosiasi merek handphone yang dianggap penting oleh konsumen, sehingga berguna sebagai dasar untuk unsur-unsur pertanyaan yang disusun pada angket kedua. Pada angket pertama ini konsumen diminta untuk menjawab pertanyaan dengan sangat setuju sampai dengan sangat tidak setuju (skala interval 4 ruas) dari 15 pertimbangan asosiasi merek handphone yang ditawarkan peneliti, tetapi konsumen masih diberi kesempatan untuk menambah atau merubah asosiasi yang sudah ada.

Angket ini disebarkan kepada 20 responden dengan teknik convenience sampling, yaitu dengan memberikan angket kepada konsumen yang pernah menggunakan produk handphone merek Nokia, Siemens, atau Sony Ericsson yang mudah ditemui di wilayah kotamadia Yogyakarta. Hasil yang diperoleh menunjukkan 15 asosiasi atribut awal yang diajukan seluruhnya diterima, yaitu handphone dengan teknologi tercanggih, pelayanan purna jual yang baik, kualitas produk yang baik, bentuk Handphone yang fashionable, handphone yang dirancang untuk mengerti siapa anda, handphone dengan banyak pilihan (varian) produk, handphone dengan berbagai teknologi komunikasi yang mudah untuk menghubungkan setiap orang, handphone dengan kemampuan fasilitas multimedia, produk handphone yang inovatif, handphone yang portabel (dapat dihubungkan dengan perangkat elektronik lainnya (misalnya komputer), handphone yang mudah dalam penggunaannya (easy 
to use), suara yang jernih, garansi yang lama, sinyal yang kuat, handphone dengan tingkat radiasi yang rendah. Di samping itu terdapat tambahan 4 (empat) asosiasi merek baru, yaitu handphone dengan harga yang kompetitif, handphone dengan bentuk yang kecil/ mungil, harga jual kembali (reselling price) yang stabil/tidak terlalu jatuh, dan handphone dengan berat fisik yang ringan. Sehingga secara keseluruhan merek yang akan digunakan sebagai dasar untuk angket kedua menjadi 19.

Adapun angket kedua disebarkan masing-masing kepada 96 konsumen di wilayah Kota Yogyakarta yang pernah menggunakan produk handphone merek Nokia, Siemens, atau Sony Ericsson serta dilakukan secara convenience sampling. Sehingga seluruh angket yang disebarkan menjadi sebanyak 288 buah.

Angket kedua yang akan dijadikan data untuk analisis utama penelitian ini, berisi 2 (dua) kelompok pertanyaan. Kelompok pertama berupa pertanyaan tentang karakteristik konsumen, yaitu gender, yang dibedakan berdasarkan kelompok pria dan wanita, usia (< 25 tahun, 25 - 40 tahun, dan $>40$ tahun), pekerjaan (pelajar/mahasiswa, karyawan/wiraswasta, dan PNS/ABRI/POLRI), serta pengeluaran pribadi per bulan (<Rp1.000.000, Rp1.000.000 - Rp3.000.000, dan > Rp3.000.000). Sedangkan kelompok pertanyaan kedua didasarkan kepada 19 asosiasi merek handphone yang diperoleh dari hasil angket pertama, dengan memberikan alternatif jawaban yang bersifat dikotomi (ya atau tidak).

\section{Metode Analisis Data}

Data yang diperoleh dari angket kedua akan dianalisis dengan menggunakan pendekatan Cochran $\mathrm{Q}$ test dan Chi Square test. Uji Cochran digunakan untuk menetapkan keberadaan hubungan antara variabel-variabel yang diteliti, dengan data yang dianalisis berupa skala pengukuran nominal atau untuk informasi terpisah dua (dikotomi), misalnya informasi ya atau tidak. Dalam penelitian ini berarti berupa jawaban pertanyaan dari 19 asosiasi pada masing-masing merek handphone Nokia, Siemens, atau Sony Ericsson. Dari uji Cochran ini dapat ditentukan asosiasi merek yang perlu ditonjolkan oleh pemasar dalam melakukan kebijakan pemasarannya. Dari penelitian sebelumnya, sebelumnya uji Cochran ini pernah dilakukan dengan baik oleh Basyir (2003) dan Sigit (2003).

Sedangkan prosedur analisis Cochran $\mathrm{Q}$ test yang harus dilakukan untuk masing-masing merek adalah sebagai berikut:

1. Menetapkan hipotesis operasional, yaitu:

Ho : Semua asosiasi merek handphone mempunyai proporsi jawaban "ya" yang sama

$\mathrm{Ha}$ : Semua asosiasi merek handphone mempunyai proporsi jawaban "ya" yang berbeda

2. Menentukan nilai kritis pengujian, yaitu dengan taraf signifikansi $(a)=0.05$

3. Menetapkan kriteria penolakan hipotesis, yaitu:

Terima Ho, jika probabilitas $(p)>0,05$

Tolak Ho, jika probabilitas $(p)<0,05$ 
4. Menghitung probabilitas (p), yaitu dengan dengan metode Cochran dan Program pengolah data SPSS versi 10

5. Mengambil keputusan, yaitu dengan merujuk prosedur (3) dan (4).

Hasil yang diinginkan dari proses ini adalah jika Ho diterima ( $p>0,05)$. Seandainya terjadi hasil sebaliknya (Ho ditolak, atau $p<0,05$ ), maka proses diulang kembali dengan melakukan prosedur (1) sampai dengan (5), tetapi dengan melakukan iritasi atau mengeluarkan salah satu asosiasi merek yang mempunyai jawaban"ya" yang paling sedikit. Demikian seterusnya dilakukan sampai dengan dapat ditemui keputusan Ho diterima, yang berarti bahwa jawaban "ya" untuk semua asosiasi merek yang tersisa adalah sama.

Selanjutnya uji Chi Square digunakan untuk menguji hipotesis adanya perbedaan asosiasi merek handphone tertentu menurut karakteristik konsumen. Asosiasi merek tersebut adalah dari hasil yang diperoleh melalui analisis dengan metode Qochran. Dengan Uji Chi Square dapat ditentukan perlu-tidaknya pemberian perlakuan pemasaran yang berbeda kepada kelompok konsumen tertentu dibandingkan dengan kelompok konsumen yang lain. Pengujian hipotesis ini juga menggunakan taraf signifikansi 5\%.

\section{HASIL ANALISIS}

Hasil analisis data dan pembahasan ini dilakukan dengan mendasarkan pada penyajian tabel. Tabel 1 merupakan representasi dari jawaban konsumen tentang asosiasi mereka pada masing-masing handphone merek Nokia, Siemens, dan Sony Ericsson serta ranking banyaknya jawaban "ya" konsumen. Tabel 2 menunjukkan rekapitulasi pengujian data dari Tabel 1 dengan pendekatan Uji Qochran, tahap demi tahap, taraf siginifikansi (sig) uji dan mengiritasi (mengeluarkan) asosiasi merek handphone tertentu dengan jawaban "ya" terkecil dari setiap tahapnya.

Sedangkan Tabel 3, 5 dan 7 merupakan hasil perhitungan dengan Uji Chi Square dengan taraf signifikansi ujinya. Adapun Tabel 4, 6, dan 8 mencerminkan distribusi proporsi kelompok konsumen, jika ditemui hasil simpulan Uji Chi Square (Tabel 3, 4, dan 7) yang menyatakan ada perbedaan asosiasi merek handphone tertentu berdasarkan karakteristik konsumen.

\section{Rekapitulasi Data Asosiasi Atribut}

Data asosiasi dari masing-masing handphone merek Nokia, Siemens, dan Sony Ericsson yang diperoleh melalui Angket kedua ditunjukkan pada Tabel 1. Dari Tabel 1 tersebut dapat terlihat bahwa dari 96 orang masing-masing konsumen handphone merek Nokia, Siemens atau Sony Erecsson mempunyai jawaban asosiasi merek yang berbeda, baik dari jumlah jawaban "ya" maupun rangking jawaban tersebut. Hampir semua konsumen menyatakan bahwa merek-merek tersebut cenderung mempunyai asosiasi merek seperti yang diteliti, kecuali asosiasi handphone merek Nokia yang mempunyai radiasi yang rendah; harga jual kembali 
yang stabil (tidak terlalu jatuh harga) pada handphone merek Siemens, serta pada merek Sony Ericsson untuk tingkat radiasi yang rendah dan harga jual kembali yang stabil (tidak terlalu jatuh harga).

Tabel 1. Rekapitulasi Asosiasi Merek Nokia, Siemens, dan Sony Ericsson

\begin{tabular}{|l|l|c|c|c|c|c|c|c|c|c|}
\hline \multirow{2}{*}{ No. } & \multirow{2}{*}{ Asosiasi merek } & \multicolumn{3}{|c|}{ Nokia } & \multicolumn{3}{c|}{ Siemens } & \multicolumn{3}{c|}{ Sony Ericsson } \\
\cline { 3 - 11 } & Tidak & Ya & Rank & Tidak & Ya & Rank & Tidak & Ya & Rank \\
\hline 1. & Teknologi tercanggih & 20 & 76 & 12 & 48 & 48 & 18 & 38 & 58 & 16 \\
\hline 2. & Pelayanan purna jual & 21 & 75 & 14 & 46 & 50 & 17 & 37 & 59 & 14 \\
\hline 3. & Produk berkualitas & 12 & 84 & 7 & 26 & 70 & 4 & 15 & 81 & 3 \\
\hline 4. & Bentuk fashionable & 11 & 85 & 6 & 34 & 62 & 12 & 18 & 78 & 8 \\
\hline 5. & Rancangan yang sesuai & 18 & 78 & 11 & 34 & 62 & 13 & 33 & 63 & 12 \\
\hline 6. & Banyak varian & 3 & 93 & 2 & 30 & 66 & 7 & 13 & 83 & 2 \\
\hline 7. & Komunikasi mudah & 9 & 87 & 4 & 13 & 83 & 1 & 7 & 89 & 1 \\
\hline 8. & Fasilitas multimedia & 12 & 84 & 8 & 31 & 65 & 9 & 15 & 81 & 4 \\
\hline 9. & Produk inovatif & 7 & 89 & 3 & 34 & 62 & 14 & 19 & 77 & 9 \\
\hline 10. & Portabel & 10 & 86 & 5 & 30 & 66 & 8 & 17 & 79 & 6 \\
\hline 11. & Penggunaan mudah & 3 & 93 & 1 & 43 & 53 & 16 & 36 & 60 & 13 \\
\hline 12. & Suara jernih & 29 & 67 & 16 & 18 & 78 & 3 & 27 & 69 & 11 \\
\hline 13. & Garansi lama & 33 & 63 & 17 & 33 & 63 & 11 & 37 & 59 & 15 \\
\hline 14. & Sinyal kuat & 37 & 59 & 18 & 16 & 80 & 2 & 46 & 50 & 17 \\
\hline 15. & Radiasi rendah & 52 & 44 & 19 & 41 & 55 & 15 & 49 & 47 & 18 \\
\hline 16. & Harga kompetitif & 14 & 82 & 9 & 31 & 65 & 10 & 15 & 81 & 5 \\
\hline 17. & Bentuk mungil & 21 & 75 & 15 & 26 & 70 & 5 & 19 & 77 & 10 \\
\hline 18. & Harga jual kembali stabil & 20 & 76 & 13 & 57 & 39 & 19 & 60 & 36 & 19 \\
\hline 19. & Ringan & 15 & 81 & 10 & 26 & 70 & 6 & 17 & 79 & 7 \\
\hline
\end{tabular}

\section{Uji Cochran}

Dari data pada Tabel 1 tersebut kemudian dilakukan Uji Cochran untuk menetapkan kesamaan jawaban "ya" pada asosiasi-asosiasi pada masing-masing merek handphone yang diteliti. Pelaksanaan perhitungan menggunakan prosedur pengujian hipotesis seperti yang telah ditetapkan di muka. Hasil analisis dapat disajikan seperti yang terlihat pada Tabel 2 .

Dari Tabel 2 tersebut dapat diketahui bahwa, untuk handphone merek Nokia, pengujian tahap pertama yang dilakukan menghasilkan taraf signifikansi 0.000. Dengan demikian Ho harus ditolak, yang berarti pernyataan semua asosiasi atribut merek handphone mempunyai proporsi jawaban "ya" yang sama untuk 19 asosiasi handphone merek Nokia disimpulkan tidak benar. Oleh karena itu, proses tahap kedua harus dilakukan, tetapi dengan menghilangkan asosiasi handphone merek Nokia yang mempunyai radiasi rendah, dalam proses pengujian (karena mempunyai jawaban "ya" terendah), sehingga tersisa 18 asosiasi merek yang akan diuji pada tahap kedua. Demikian seterusnya dilakukan proses pengujian sampai sebanyak 14 tahap. 
Tabel 2. Rekapitulasi Uji Cochran Asosiasi Merek Nokia, Siemens, dan Sony Ericsson

\begin{tabular}{|c|c|c|c|c|c|c|}
\hline \multirow{2}{*}{ Tahapan uji } & \multicolumn{2}{|c|}{ Nokia } & \multicolumn{2}{|c|}{ Siemens } & \multicolumn{2}{|c|}{ Sony Ericsson } \\
\hline & Iritasi & Sig. & Iritasi & Sig. & Iritasi & Sig. \\
\hline Tahap 1 & ---- & 0.000 & $-\overline{--}$ & 0.000 & --- & 0.000 \\
\hline Tahap 2 & No: 15 & 0.000 & No: 18 & 0.000 & No: 18 & 0.000 \\
\hline Tahap 3 & No: 14 & 0.000 & No: 1 & 0.000 & No: 15 & 0.000 \\
\hline Tahap 4 & No: 13 & 0.000 & No: 2 & 0.000 & No: 14 & 0.000 \\
\hline Tahap 5 & No: 12 & 0.000 & No: 11 & 0.000 & No: 1 & 0.000 \\
\hline Tahap 6 & No: 17 & 0.000 & No: 15 & 0.000 & No: 13 & 0.000 \\
\hline Tahap 7 & No: 2 & 0.000 & No: 4 & 0.000 & No: 2 & 0.000 \\
\hline Tahap 8 & No: 18 & 0.000 & No: 5 & 0.000 & No: 11 & 0.000 \\
\hline Tahap 9 & No: 1 & 0.002 & No: 9 & 0.001 & No: 5 & 0.008 \\
\hline Tahap 10 & No: 5 & 0.017 & No: 13 & 0.002 & No: 12 & 0.185 \\
\hline Tahap 11 & No: 19 & 0.033 & No: 8 & 0.003 & ---- & ---- \\
\hline Tahap 12 & No: 16 & 0.042 & No: 16 & 0.005 & $-\cdots$ & ---- \\
\hline Tahap 13 & No: 3 & 0.035 & No: 6 & 0.007 & --- & ---- \\
\hline Tahap 14 & No: 8 & 0.064 & No: 10 & 0.027 & --- & ---- \\
\hline Tahap 15 & --- & --- & No: 13 & 0.033 & ---- & ---- \\
\hline Tahap 16 & 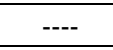 & --- & No: 17 & 0.069 & --- & ---- \\
\hline
\end{tabular}

Pada tahap keempat belas taraf signifikansi yang dihasilkan adalah 0,064. $\mathrm{Hal}$ itu berarti Ho dinyatakan diterima, atau asosiasi merek yang tersisa pada handphone merek Nokia mempunyai proporsi jawaban "ya" yang telah sama. Oleh karena itu proses pengujian dihentikan, sehingga sisa asosiasi merek yang dimiliki handphone merek Nokia dapat teridentifikasi dan membentuk brand image yang sangat kuat sebanyak 6 (enam) asosiasi merek, yaitu bentuk handphone yang fashionable, handphone dengan banyak pilihan/varian produk, handphone dengan berbagai teknologi komunikasi yang mudah untuk menghubungkan setiap orang, produk handphone yang inovatif, handphone yang portabel/dapat dihubungkan dengan perangkat elektronik lainnya, dan handphone yang mudah dalam penggunaannya (easy to use).

Untuk handphone merek Siemens dan Sony Erecsson proses pengujian sama seperti pada merek Nokia. Untuk merek Siemens, untuk memperoleh proporsi jawaban "ya" yang sama dari sejumlah asosiasi merek yang ada diperlukan proses pengujian sebanyak 16 tahap, sehingga terdapat 4 (empat) asosiasi merek tersisa yang dipunyainya serta membentuk brand image yang sangat kuat, yaitu handphone dengan berbagai teknologi komunikasi yang mudah untuk menghubungkan setiap orang, suara yang jernih, sinyal yang kuat, serta handphone dengan berat fisik yang ringan.

Adapun pada merek Sony Erecsson diperlukan proses pengujian sebanyak 10 tahap. Dengan demikian sisa asosiasi merek yang dianggap melekat atau dimiliki oleh handphone merek Sony Erecsson dan membentuk brand image yang sangat 
kuat menjadi 10 asosiasi merek, yaitu kualitas produk yang baik, bentuk handphone yang fashionable, handphone dengan banyak pilihan, handphone dengan berbagai teknologi komunikasi yang mudah untuk menghubungkan setiap orang, dan handphone dengan kemampuan fasilitas multimedia. Di samping itu juga asosiasi atribut produk handphone yang inovatif, handphone yang portable/ dapat dihubungkan dengan perangkat elektronik lainnya, misal: komputer, handphone dengan harga yang kompetitif, handphone dengan bentuk yang kecil/ mungil, serta handphone dengan berat fisik yang ringan.

\section{Uji Chi Square}

Asosiasi merek yang tersisa dan membentuk brand image yang sangat kuat pada masing-masing handphone merek Nokia, Siemens atau Sony Erecsson -dari hasil yang diperoleh melalui analisis Qochran, kemudian digunakan untuk menguji ada tidaknya perbedaan asosiasi merek handphone tertentu menurut karakteristik konsumen (gender, usia, pekerjaan, pengeluaran pribadi per bulan) dengan memakai metode Chi Square.

Dari hasil pengujian Chi Square yang telah dilakukan antara asosiasi merek dengan karakteristik konsumen handphone merek Nokia, dapat dilihat tingkat signifikansi hitungnya seperti yang diringkas dalam Tabel 3.

Tabel 3. Uji Chi Square Asosiasi Merek Nokia menurut Karakteristik Konsumen

\begin{tabular}{|l|c|c|c|c|}
\hline \multirow{2}{*}{ Asosiasi merek } & \multicolumn{4}{c|}{ Karakteristik } \\
\cline { 2 - 5 } & Gender & Usia & Kerja & Pengeluaran \\
\hline Bentuk fashionable & 0.600 & 0.136 & 0.525 & 0.742 \\
\hline Banyak varian & 0.416 & 0.484 & 0.691 & 0.206 \\
\hline Komunikasi mudah & 0.031 & 0.438 & 0.816 & 0.263 \\
\hline Produk inovatif & 0.961 & 0.355 & 0.745 & 0.822 \\
\hline Portabel & 0.674 & 0.869 & 0.298 & 0.461 \\
\hline Penggunaan mudah & 0.416 & 0.059 & 0.104 & 0.284 \\
\hline
\end{tabular}

Dari Tabel 3 dapat diketahui perhitungan Uji Chi Square seluruhnya menghasilkan taraf signifikansi yang lebih besar dari $5 \%(p>0,05)$, sehingga hipotesis ke-2 harus ditolak, kecuali untuk asosiasi bahwa merek Nokia mempunyai teknologi komunikasi yang mudah untuk menghubungkan setiap orang yang dibedakan berdasarkan gender konsumennya. Khusus untuk asosiasi merek tersebut perlu lebih diperjelas lagi distribusi nilainya, sehingga dapat diketahui asosiasi handphone merek Nokia, yang membentuk brand image yang sangat kuat ini lebih banyak terjadi pada kelompok pria atau wanita. Tabel 4 disajikan untuk memperjelas distribusi nilai hasil Uji Chi Square di atas.

Tabel 4 tersebut dapat menunjukkan bahwa ternyata secara total $(90,6 \%)$ kedua kelompok konsumen tersebut cenderung menyatakan bahwa Nokia mempunyai teknologi komunikasi yang mudah untuk menghubungkan setiap orang, 
namun jika dicermati terdapat perbedaan proporsi yang cukup berarti, dengan kecenderungan kelompok pria lebih banyak dibandingkan dengan wanita (96,3\% berbanding $83,3 \%)$.

Tabel 4. Distribusi Asosiasi Komunikasi Mudah pada Merek Nokia menurut Gender Konsumen

\begin{tabular}{|c|c|c|c|}
\hline \multirow{2}{*}{ Jawaban } & \multicolumn{2}{|c|}{ Gender } & \multirow{2}{*}{ Total } \\
\cline { 2 - 3 } & Pria & Wanita & \\
\hline Tidak & $2(3,7 \%)$ & $7(16,7 \%)$ & $9(9,4 \%)$ \\
\hline Ya & $52(96,3 \%)$ & $35(83,3 \%$ & $87(90,6 \%)$ \\
\hline Total & $54(100 \%)$ & $42(100 \%)$ & $96(100 \%)$ \\
\hline
\end{tabular}

Untuk merek Siemens, dapat diperoleh taraf signifikansi hasil pengujian asosiasi merek menurut karakteristik konsumen (gender, usia, pekerjaan, pengeluaran pribadi per bulan) seperti yang disajikan pada Tabel 5 .

Tabel 5. Uji Chi Square Asosiasi

Merek Siemens menurut Karakteristik Konsumen

\begin{tabular}{|l|c|c|c|c|}
\hline \multirow{2}{*}{\multicolumn{1}{|c|}{ Asosiasi merek }} & \multicolumn{4}{c|}{ Karakteristik } \\
\cline { 2 - 5 } & Gender & Usia & Kerja & Pengeluaran \\
\hline Komunikasi mudah & 0.144 & 0.732 & 0.752 & 0.537 \\
\hline Suara jernih & 0.426 & 0.068 & 0.808 & 0.226 \\
\hline Sinyal kuat & 0.711 & 0.091 & 0.527 & 0.331 \\
\hline Ringan & 0.007 & 0.478 & 0.371 & 0.203 \\
\hline
\end{tabular}

Dari Tabel 5 dapat terlihat semua hipotesis ke-2 harus ditolak, karena menghasilkan taraf signifikansi hitung yang lebih besar dari $5 \%(p>0,05)$, kecuali untuk asosiasi bahwa merek Siemens mempunyai berat fisik yang ringan yang dibedakan berdasarkan kelompok gender konsumennya. Karena itu, untuk lebih memperjelas distribusi nilainya diperlukan penyelidikan pada asosiasi merek tersebut, sehingga dapat diketahui kecenderungan antar kelompok pria atau wanita yang membentuk brand image dari handphone merek Siemens. Pada Tabel 6 ditunjukkan distribusi nilai asosiasi merek dari hasil pengujian Chi Square di atas.

Tabel 6.Distribusi Asosiasi Bobot yang Ringan pada Merek Siemens menurut Gender Konsumen

\begin{tabular}{|c|c|c|c|}
\hline \multirow{2}{*}{ Jawaban } & \multicolumn{2}{|c|}{ Gender } & \multirow{2}{*}{ Total } \\
\cline { 2 - 3 } & Pria & Wanita & \\
\hline Tidak & $21(37,5 \%)$ & $5(12,5 \%)$ & $26(27,1 \%)$ \\
\hline Ya & $35(62,5 \%)$ & $35(87,5 \%)$ & $70(72,9 \%)$ \\
\hline Total & $56(100 \%)$ & $40(100 \%)$ & $96(100 \%)$ \\
\hline
\end{tabular}


Tabel 6 menginformasikan, secara total konsumen pria dan wanita cenderung berpendapat bahwa handphone merek Siemens mempunyai berat fisik yang ringan (72,9\%). Sedangkan secara absolut distribusi jawaban "ya" kedua kelompok konsumen tersebut adalah terlihat sama (35 orang), tetapi jika dilakukan perbandingan berdasarkan nilai relatif, ternyata proporsi kelompok wanita lebih baik dibandingkan dengan kelompok pria, yaitu dengan nilai 87,5\% berbanding 62,5\%.

Adapun perhitungan Chi Square pada handphone merek Sony Ericsson dapat diperoleh taraf signifikansi perhitungan untuk uji beda asosiasi merek berdasarkan karaktereristik konsumen seperti yang disajikan pada Tabel 7 .

Tabel 7. Uji Chi Square Asosiasi Merek Sony Ericsson menurut Karakteristik Konsumen

\begin{tabular}{|l|c|c|c|c|}
\hline \multirow{2}{*}{ Asosiasi merek } & \multicolumn{4}{c|}{ Karakteristik } \\
\cline { 2 - 5 } & Gender & Usia & Kerja & Pengeluaran \\
\hline Produk berkualitas & 0.874 & 0.123 & 0.012 & 0.168 \\
\hline Bentuk fashionable & 0.622 & 0.169 & 0.002 & 0.319 \\
\hline Banyak varian & 0.192 & 0.187 & 0.118 & 0.107 \\
\hline Komunikasi mudah & 0.024 & 0.676 & 0.428 & 0.525 \\
\hline Fasilitas multimedia & 0.469 & 0.263 & 0.156 & 0.347 \\
\hline Produk inovatif & 0.801 & 0.329 & 0.069 & 0.131 \\
\hline Portabel & 0.200 & 0.308 & 0.222 & 0.643 \\
\hline Harga kompetitif & 0.331 & 0.099 & 0.203 & 0.791 \\
\hline Bentuk mungil & 0.801 & 0.125 & 0.439 & 0.437 \\
\hline Ringan & 0.456 & 0.118 & 0.191 & 0.394 \\
\hline
\end{tabular}

Dari Tabel 7 dapat diketahui hanya ada 3 (tiga) asosiasi merek yang menghasilkan taraf signifikansi yang lebih kecil dari $5 \%(p<0,05)$, yaitu untuk asosiasi handphone merek Sony Ericsson sebagai produk yang berkualitas dan bentuknya fashionable yang dibedakan menurut jenis pekerjaan konsumen, serta asosiasi merek handphone dengan teknologi komunikasi yang mudah untuk menghubungkan setiap orang berdasarkan perbedaan gender konsumen, sehingga hipotesis ke-2 untuk ketiga asosiasi merek tersebut gagal ditolak. Sedangkan untuk asosiasi merek yang lain, karena taraf signifikansi hitung yang diperoleh menghasilkan lebih besar dari 5\% ( $p>0,05)$, maka hipotesis ke-2 harus ditolak.

Untuk mempertajam distribusi nilai ketiga asosiasi merek yang membentuk brand image yang sangat kuat berdasarkan kelompok-kelompok karakteristik pekerjaan dan gender tersebut, seperti yang telah dilakukan pengujian Chi Square di atas, disajikan informasi seperti yang terlihat pada Tabel 8. 


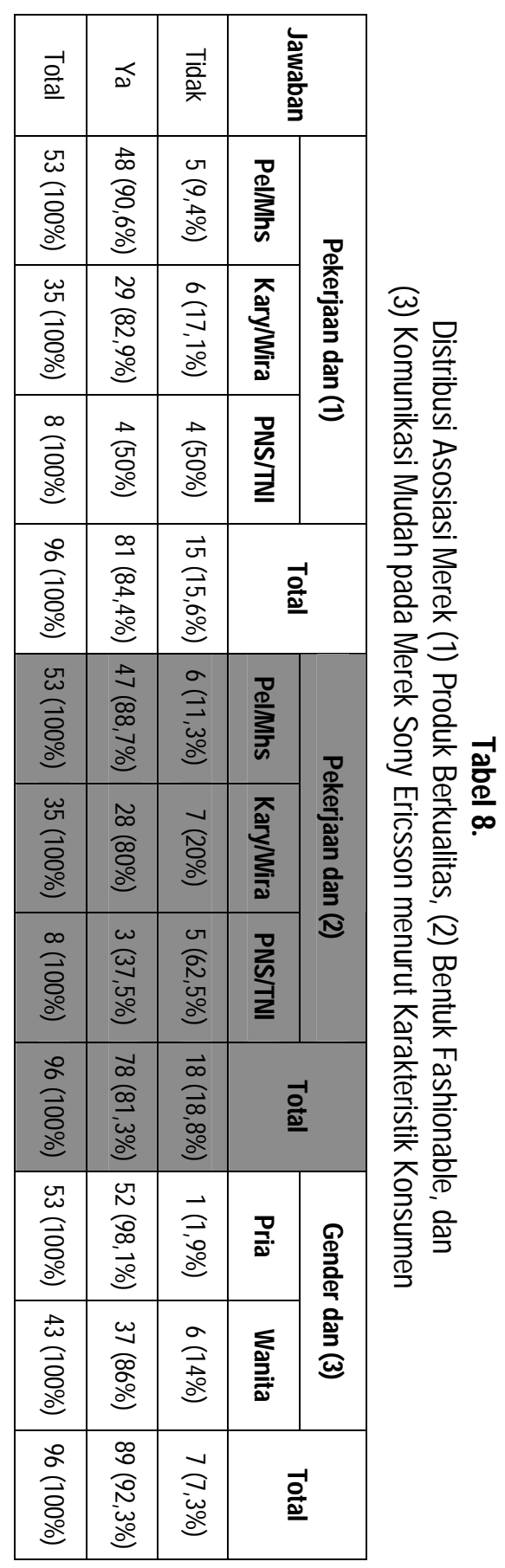


Tabel 8 tersebut menunjukkan bahwa berdasarkan pada pekerjaan konsumen ternyata secara total kelompok pelajar/mahasiswa dan karyawan/wiraswasta cenderung menyatakan bahwa handphone merek Sony Ericsson sebagai produk yang kualitasnya baik dan mempunyai bentuk yang fashionable, dengan kecenderungan kelompok pelajar/mahasiswa yang lebih tinggi distribusi proporsinya $(90,6 \%$ dan $88,7 \%$ ) dibandingkan dengan kelompok karyawan/wiraswasta (82,9\% dan 80\%), bahkan jauh lebih tinggi dibandingkan dengan kelompok PNS/TNI/POLRI (50\% dan $37,5 \%)$.

Sedangkan menurut kelompok gender, secara total memang terdapat 92,3\% konsumen yang cenderung berpendapat bahwa handphone merek Sony Ericsson mempunyai teknologi komunikasi yang mudah untuk menghubungkan setiap orang. Namun jika dipisahkan berdasarkan kelompok-kelompok gendernya ternyata diperoleh kecenderungan perbedaan distribusi proporsi yang cukup berarti, yaitu kelompok pria lebih banyak dibandingkan dengan wanita (98,1\% berbanding $86 \%)$.

\section{PEMBAHASAN}

Hasil analisis yang diperoleh di atas dapat digunakan untuk membuat program pemasaran yang relevan, sehingga pemasar handphone merek Nokia, Siemens dan Sony Ericsson dapat lebih fokus dalam menjalankan kegiatan pemasarannya, khususnya untuk konsumen di wilayah Kotamadia Yogyakarta.

Hasil Uji Cochran menunjukkan bahwa dari 19 asosiasi merek yang diteliti pada handphone merek Nokia, Siemens dan Sony Erecsson dapat diperoleh berturut-turut 6 (enam), 4 (empat) dan 10 kelompok asosiasi merek yang bisa membentuk brand image yang sangat kuat pada masing-masing merek. Hal ini mengindikasikan bahwa sesungguhnya kelompok asosiasi dari masing-masing merek tersebut dapat dimanfaatkan dan dieksploitasi dalam mengembangkan program pemasaran oleh masing-masing pemasar, khususnya dalam mendesain produk dan melakukan komunikasi pemasaran.

Namun akan lebih baik lagi sekiranya masing-masing merek lebih menfokuskan keunggulan atau kekhasan asosiasi merek yang dipunyainya, yang tidak dijumpai pada merek yang lain. Misalnya untuk merek Nokia, mereka bisa lebih mengeksploitasi karakteristik produk dan iklannya hanya pada asosiasi merek sebagai handphone yang mudah dalam penggunaan, karena untuk 5 (lima) asosiasi merek yang lain relatif sama seperti yang dipunyai oleh merek Siemens dan Sony Ericsson. Sedangkan untuk merek Siemens lebih mengembangkan pada asosiasi sebagai merek handphone yang mempunyai suara jernih dan sinyal yang kuat, serta merek Sony Ericsson lebih menekankan pada asosiasi sebagai merek handphone dengan kualitas produk yang baik, kemampuan fasilitas multimedia, harga yang kompetitif dan bentuk yang kecil/mungil.

Resiko yang harus ditanggung dari pilihan tersebut adalah asosiasi merek yang diunggulkan itu bukan asosiasi utama atau yang selama ini telah menjadi 
trademark dari merek handphone tersebut. Untuk merek Nokia, asosiasi merek yang mungkin dapat dipilih kebetulan memang berada di peringkat pertama. Tetapi pada merek Siemens, asosiasi merek yang membentuk brand image yang sangat kuat tersebut adalah peringkat ke-2 dan ke-3, sedangkan untuk merek Sony Ericsson justru di peringkat ke-3, 4, 5 dan ke-10. Meskipun sebagai suatu pilihan kebijakan pemasaran yang sulit, tetapi dalam jangka panjang resiko tersebut mungkin dapat menguntungkan pemasar, karena masing-masing merek dapat mempunyai keunikan yang berbeda dengan merek lain, sehingga dapat digunakan sebagai bagian dari kegiatan positioning merek yang ada.

Pilihan kebijakan pemasaran yang lain dan berbeda dapat dilakukan dengan menggunakan hasil Uji Chi Square, terutama jika pemasar bermaksud mengfokuskan kegiatan pemasarannya pada kelompok konsumen tertentu. Namun resiko yang harus ditanggung dari pilihan ini juga seperti pada pilihan keunikan asosiasi merek yang dapat dikembangkan di atas, yaitu asosiasi merek yang diunggulkan itu bukan yang utama dari yang dipunyai oleh merek handphone yang ada. Misalnya untuk merek Nokia mungkin justru perlu menonjolkan asosiasi merek teknologi komunikasi yang mudah untuk menghubungkan setiap orang -yang notabene beradi di peringkat ke-4, terutama apabila produk akan ditujukan kepada segmen konsumen pria. Dalam hal kebijakan format periklanan, pilihan penggunaan kombinasi unsur-unsur asosiasi merek tersebut dengan endoser pria kemungkinan lebih baik atau berhasil untuk lebih menguatkan brand image dibandingkan endoser wanita.

Penjelasan yang sama seperti merek Nokia tersebut dapat dilakukan juga pada handphone merek Sony Ericsson, karena hasil Uji Chi Square kedua merek tersebut relatif menghasilkan kondisi yang sama, meskipun peringkat asosiasi merek teknologi komunikasi yang mudah untuk menghubungkan setiap orang pada merek Sony Ericsson ini lebih baik, yaitu di peringkat pertama. Di samping itu, khusus untuk merek Sony Ericsson, pilihan yang lain dapat juga dilakukan, terutama jika ingin membedakan segmen konsumennya dan format periklanan yang akan dilakukan dengan merek Nokia, yaitu dengan menggunakan gabungan unsur-unsur asosiasi merek handphone yang mempunyai kualitas produk yang baik (peringkat ke-3) dan fashionable (peringkat ke-8) dengan memanfaatkan endoser pelajar/mahasiswa.

Sedangkan pemilihan asosiasi merek dan penekanan kepada kelompok segmen tertentu pada merek Siemens berbeda lagi. Pada merek Siemens, desain produk yang dapat menghasilkan berat fisik yang ringan (peringkat ke-4) dan ditujukan untuk konsumen wanita mungkin menjadi pilihan yang terbaik. Demikian pula format periklanan dengan menggunakan gabungan unsur-unsur asosiasi merek handphone dengan berat fisik yang ringan dan endoser wanita dapat memberikan kemungkinan hasil yang lebih baik dalam menguatkan brand image dibandingkan jika memakai endoser pria. 


\section{PENUTUP}

Hasil analisis dapat memberikan pilihan-pilihan dalam menetapkan kebijakan pemasaran yang dapat berbeda satu sama lain, baik pada suatu merek maupun antar merek handphone Nokia, Siemens dan Sony Erecsson. Resiko yang perlu ditanggung atas setiap pilihan didasarkan kepada asosiasi merek yang digunakan sebagai keunikan brand image dan kelompok segmen konsumen yang mungkin perlu dikembangkan oleh masing-masing merek handphone tersebut.

\section{DAFTAR PUSTAKA}

Aaker D.A., (1991), Managing Brand Equity: Capitalizing on the Value of a Brand Name, Toronto: Maxwell Macmillan.

, (1992a), Strategic Market Management, $3^{\text {th }}$ ed., New York: John Wiley \& Sons, Inc.

, (1992b), "Managing the Most Important Asset: Brand Equity," Planning Review, 20 (5): 56-60

Alvin, A.A. (1993), "The Future Challenge to Market Research," Marketing Research, 5 (2): $12-19$

Assael, H. (1992), Consumer Behavior and Marketing Action, $4^{\text {th }}$ ed., Boston: PWS-KENT Publishing Company.

Basyir, A. (2003), Analisis Ekuitas Merek Pasta Gigi Close Up, Skripsi Sarjana (tidak dipublikasikan), Yogyakarta: Fakultas Ekonomi Universitas Islam Indonesia.

Bleckwell, R.D., P.W. Miniard and J.F. Engel (2001), Consumer behavior, gth ed., Orlando: Hourcourt College Publishers.

Blythe, J. (1997), The Essence of Consumer Behavior, London: Prentice Hall.

Bowerman, B.L., R.T. O'Connell and L.L. Hand (2001), Business Statistics in Practice, $2^{\text {th }}$ ed., New York: The McGrow-Hill Companies, Inc.

Chen, A.C-H (2001), "Using Free Association to Examine the Relationship between the Characteristics of Brand Association and Brand Equity," Journal of Product \& Brand Management, 10 (7): 439-451.

Davis, D.F. (2002), "Fuzzy sets, Uncertainty, and Brand Associations," American Marketing Associations, 13: 312-319.

Del Rio, A.B., R. Vesques dan V. Igle (2001), "The Effects of Brand Associations on Consumer Response," The Journal of Consumer Marketing, 18 (4/5): 410-426

East, R. (1997), Consumer Behaviour: Advances and Applications in Marketing, London: Prentice Hall. 
Firdanianty (2003), "Sanggupkah Samsung Menggoyang Nokia?" Swa, No. 14/XIX/10-23 Juli 2003

Foxall, G., R. Goldsmith and S. Brown (1998), Consumer Psychology for Marketing, $2^{\text {th }}$ ed., London: International Thomson Business Press.

Grace, D. and A. O'Cass (2002), "Brand Association: Looking Through the Eye of the Beholder," Qualitative Market Research: An International Journal, 5 (2): 96111.

Hoeffler, S. dan K.L. Keller (2003), "The Marketing Adventages of Strong Brands," Journal of Brand Management, 10 (6): 421-437

Janiszewski C. dan S.M.J. Van Osselaer (2000), "a Connectionist Model of BrandQuality Associations," Journal of Marketing Research, 37 (3): 331-350.

Keller, K.L. (1993), "Conceptualizing, Measuring, and Managing Customer-based Brand Equity," Journal of Marketing, 57 (1): 1-22

, (1998), Building, Measuring, and Managing Brand Equity, New Jersey: Prentice Hall

Keller, K.L., S.E. Heckler dan M.J. Houston (1998), 'The Effect of Brand Name Suggestiveness on Advertising Recall," Journal of Marketing, 62 (1): 48-58

Kotler, P. (2003), Marketing Management, $11^{\text {th }}$ ed., New Jersey: Prentice Hall

Krishnan, H.S. (1996), "Characteristics of Memory Associations: a Consumer-based Brand Equity Perspective," International Journal of Market Research, 13 (4): 389-406

Loudon, D.L. and A.J. Della Bitta (1993), Consumer Behavior: Concept and Applications, $4^{\text {th }}$ ed. New York: McGraw-Hill, Inc.

Low, G.S. and C.W. Lamb Jr (2000), "The Measurement and Dimensionality of Brand Association," Journal of Product \& Brand Management, 9 (6): 350-368.

Mackay, M.M (2001), "Evaluation of Brand Equity Measures: Further Empirical Results," Journal of Product \& Brand Management, 10 (1): 38-51.

Malhotra, N.K. (1999), Marketing Research: An Apllied Orientation, $3^{\text {th }}$ ed., New Jersey: Prentice Hall International, Inc.

Moven, J.C. and M. Minor (1998), Consumer Behavior, $5^{\text {th }}$ ed., New Jersey: Prentice Hall International, Inc.

Newbolt, P. (1995), Statistics for Business \& Economics, $4^{\text {th }}$ ed., New Jersey: Prentice-Hall International, Inc. 
Peter, J.P. and J.C. Olson (1996), Consumer Behavior and Marketing Strategy, $4^{\text {th }}$ ed., Chicago: Richard D. Irwin, Inc.

Quester, P. and F. Farrely (1998), "Brand Association and Memory Decay Effects of Sponsorship: the Case of Australian Formula One Grand Prix," Journal of Product \& Brand Management, 7 (6): 539-556.

Schiffman, L.G. and L.L. Kanuk (1997), Consumer Behavior, 6 ${ }^{\text {th }}$ ed., New Jersey: Prentice Hall International, Inc.

Sekaran, U. (2003), Research Methods for Business, $4^{\text {th }}$ ed., Toronto: John Wiley \& Sons, Inc.

Solomon, M.R. (1999), Consumer Behavior, $4^{\text {th }}$ ed., New Jersey: Prentice Hall, Inc.

Sigit, R.C. (2003), Analisis Elemen-elemen Brand Equity dalam Kaitannya dengan Loyalitas Konsumen: Studi Kasus Produk Kartu GSM Prabayar Merek SIMPATI, Skripsi Sarjana (tidak dipublikasikan), Yogyakarta: Fakultas Ekonomi Universitas Islam Indonesia.

Simamora, B. (2003), Membongkar Kotak Hitam Konsumen, Jakarta: Gramedia Pustaka Utama.

Supphellen, M. (2000), "Understanding Core Brand Equity: Guideliness for in-depth Elicitation of Brand Associations," International Journal of Market Research, 42 (3): 319-331.

Swa (2003), "Indonesian Best Brand 2003," No. 14/XIX/10-23 Juli 2003.

Uggla, H. (2004), "The Brand Associations Base: a Conceptual Model for Strategically Leveraging Partner Bran Equity," Journal of Brand Management, 12 (2): 105-124.

Upshaw, L.B. (2001), "Building a Brand.comm," Design Management Journal, 12 (1): 34-39.

Vaidyanathan, R. and P. Aggarwal (2000), "Strategic Brand Alliance: Implications of Ingredient Branding for National and Private Label Brand," Journal of Product \& Brand Management, 9 (4): 214-228.

Washburn, J.H., B.D. Till and R. Priluck (2000), "Co-Branding: Brand Equity and Trial Effects," Journal of Consumer Marketing, 17 (7): 591-604.

Wells, W.D. and D. Prensky (1996), Consumer Behavior, New York: John Wiley \& Sons, Inc. 